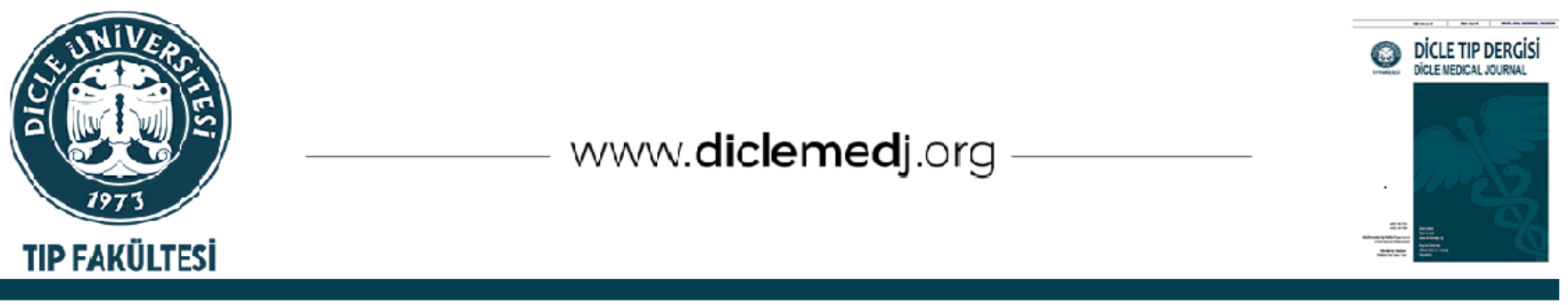

Original Article / Özgün Araştırma

\title{
Effects of electroporation on cytotoxicity of 4-aminopyrimidin-2- (1H)-one based ligand and its Cobalt (II) and Ruthenium (II) complexes in MCF-7 cancer cells
}

\author{
Mehmet Esref Alkis iD 1 \\ 1 Department of Occupational Health and Safety, Faculty of Health Sciences, Muş Alparslan University, Muş, Turkey
}

Received: 06.02.2021; Revised: 01.07.2021; Accepted: 14.07.2021

\begin{abstract}
Objective: The aim of this study was to investigate the underlying causes of obstetrical disseminated intravascular coagulation (DIC) Objective: Cancer is a complicated disease and ranks near the top among the causes of death across the world. Electrochemotherapy (ECT) is a local treatment method in which chemotherapy and electroporation (EP) are used in combination to facilitate the entry of drugs into cells. The purpose of the study is to examine the cytotoxicity of the cytosine-based ligand and its cobalt and ruthenium complexes in MCF-7 cancer cells and L-929 healthy cells, and to determine the effects of EP on the anticancer activities of these compounds.

Methods: In the present study, firstly, the cytotoxic activities of the ligand and its cobalt (Co) and ruthenium (Ru) complexes were examined against MCF-7 cancer cells and L-929 healthy cells. Then, the effects of EP on the anticancer activities of these compounds were examined in MCF-7 cancer cells. Cytotoxicity activities of the compounds were determined by MTT viability test.
\end{abstract}

Results: Co(II) and Ru(II) compounds showed the best cytotoxicity against MCF-7 cancer cells, while they displayed low cytotoxicity against the L-929 healthy cells. EP increased the cytotoxicity of the compounds significantly (p<0.05). A statistically significant decrease was observed in the percentages of cell viability of ligand+EP, Co(II)+EP, and Ru(II)+EP treatment groups compared to those of the compounds-alone and control groups $(\mathrm{p}<0.05)$.

Conclusion: The results of the present study demonstrated that $\mathrm{Co}$ (II) and Ru(II) complexes may contribute as potential chemotherapeutic agents for the treatment of breast cancer and ECT can reduce the side effects of agents by providing treatment with a lower doses of compounds.

Keywords: Breast cancer, cobalt, ruthenium, cytotoxicity, electroporation

DOI: $10.5798 /$ dicletip.988061

Correspondence / Yazışma Adresi: Mehmet Esref Alkis, Department of Occupational Health and Safety, Health School of Muş Alparslan University, 49250 Muș, Turkeye-mail: me.alkis@alparslan.edu.tr 


\section{Elektroporasyonun MCF-7 kanser hücrelerinde 4-aminopirimidin-2- (1H)-on ana maddesinden sentezlenen ligand ile Kobalt (II) ve Rutenyum (II) komplekslerinin sitotoksisiteleri üzerindeki etkisi}

\section{$\ddot{0} z$}

Giriş: Kanser komplike bir hastalıktır ve dünya çapında ölüm nedenleri arasında ilk sıralarda yer almaktadır. Elektrokemoterapi (ECT), ilaçların hücrelere girişini kolaylaştırmak için kemoterapi ve elektroporasyonun (EP) birlikte kullanıldığı lokal bir tedavi yöntemidir. Bu çalışmanın amacı, sitozin ana maddesinden sentezlenmiş ligand ile onun kobalt ve rutenyum komplekslerinin MCF-7 kanser hücreleri ve L-929 sağlıklı hücrelerdeki sitotoksisitelerini incelemek ve EP'nin bu bileşiklerin antikanser aktiviteleri üzerindeki etkilerini belirlemektir.

Yöntemler: Bu çalışmada ilk olarak, ligand ile kobalt (Co) ve rutenyum (Ru) komplekslerinin sitotoksik aktiviteleri MCF7 kanser hücreleri ve L-929 sağlıklı hücrelere karşı incelendi. Daha sonra, EP'nin bu bileşiklerin antikanser aktiviteleri üzerindeki etkileri MCF-7 kanser hücrelerinde belirlendi. Bileşiklerin sitotoksisite aktiviteleri MTT canlılık testi ile değerlendirildi.

Bulgular: Co(II) ve Ru(II) bileșikleri, MCF-7 kanser hücrelerine karşı iyi sitotoksisite gösterirken, L-929 sağlıklı hücrelere karşı düşük sitotoksisite sergilediler. EP, bileşiklerin sitotoksisitesini önemli ölçüde artırdı ( $p<0.05)$. Ligand + EP, Co(II) + EP ve Ru(II) + EP tedavi gruplarının hücre canlılı̆̆ı yüzdelerinde, sadece bileşik uygulanan ve kontrol gruplarınınkine klyasla istatistiksel olarak anlamlı bir düşüş gözlendi $(\mathrm{p}<0.05)$.

Sonuç: Bu çalışmanın bulguları, Co(II) ve Ru(II) komplekslerinin meme kanserinin tedavisi için potansiyel kemoterapötik ajan olarak katkıda bulunabileceklerini ve ECT'nin daha düşük doz bileşiklerle tedaviyi sağlayarak ajanların yan etkilerini azaltabileceğini göstermiştir.

Anahtar kelimeler: Meme kanseri, kobalt, rutenyum, sitotoksisite, elektroporasyon.

\section{INTRODUCTION}

Cancer, one of the major health challenges of our age, ranks near the top among the causes of death across the world ${ }^{1}$. The number of cancer cases increases with each passing day, and proactive solutions fall short of being sufficient. Various methods are used in cancer treatment, such as surgery, chemotherapy, radiation therapy, immunotherapy, and stem cell transplantation $^{2}$. Chemotherapy, the most known among these methods, is a cytotoxic drug treatment. Chemotherapy is a treatment method in which some anti-cancer agents are used to prevent or eliminate the abnormal proliferation of cells in cancerous tissues. However, due the fact that the standard chemotherapy has a low efficacy and many side effects, there is a need for finding new drugs or increasing the standard cytostatic activity ${ }^{3}$. Breast cancer, a form of cancer that is very common, is the primary cause of cancer-related deaths among women ${ }^{4}$. The resistance of breast cancer cells to the chemotherapy drugs poses an important clinical obstacle to cancer treatment ${ }^{5}$. This in return leads to the use of drugs at high doses and the prolongation of the treatment, increasing the side effects. Therefore, there is a need for finding different treatment methods and developing new anticancer agents in order to increase the lifespan and life quality of breast cancer patients.

Considering fascinating biological activities of the Cobalt (Co) and Ruthenium (Ru) complexes and the Schiff base ligand, this study was designed to investigate their anti-cancer activities against breast cancer. Cobalt is classified as metal and its distribution is widely observed in biological structures like body and cell. The cobalt complexes' interaction with DNA has drawn a great deal of attention among scholars due to their therapeutic reagents 6 . Cobalt complexes have also been tested in terms of their potential for being a hypoxia-activated anticancer prodrug which can kill the cancer 
cells by releasing toxic ligands ${ }^{7}$. Ruthenium compounds also have a potential for being a drug candidate. They provide a reduced toxicity and it is possible to tolerate them in vivo. Ruthenium compounds have several oxidation states, various action mechanisms, and kinetics of ligand substitution, and these properties make them an alternative to be considered in the biological field 8 . In recent studies, ruthenium compounds were examined to find whether they can prevent tumor growth. These studies mainly focused on the ruthenium complexes' interactions with RNA, DNA, albumin, cytochrome c, and transferrin ${ }^{9,10}$. These compounds were examined in terms of their cytotoxicity in the breast cancer cells when used with chemotherapy electrochemotherapy.

Electrochemotherapy (ECT) is a local therapy technique in which chemotherapy and electric pulses are used in combination to facilitate the entry of drugs into cells ${ }^{11}$. When electric impulses are given to the cell, a transmembrane voltage is generated on the cell membrane. If this voltage exceeds a critical value, some temporary small pores are formed in the cell membrane, causing a significant rise in permeability and electrical conductivity of the membrane ${ }^{12}$. In this way, the entry of chemotherapy agents into cells can be facilitated and their cytotoxicity can be increased. In ECT, in general, a drug with weak permeation is absorbed by the cancer cells and consequently, demonstrates the action only in the cancer cells, which significantly reduces various side effects seen in standard systemic chemotherapy. In the literature, to the best of my knowledge, there is no research in which ECT and the anticancer drugs produced using complexes are applied in combination to the breast cancer cells. In the light of this information, the aim of the research is to investigate the cytotoxicity of the cytosinebased ligand and its cobalt and ruthenium complexes in MCF-7 cancer cells and L-929 healthy cells, and to determine the electroporation's effects on the anti-cancer activity of these compounds in the MCF-7 cancer cell line.

\section{METHODS}

\section{Cell preparation}

Human breast adenocarcinoma cells (MCF-7) (Passage No. 6) and healthy fibroblast cells (L929) (Passage No. 7) were used in the study. The cell lines were provided from Inonu University's Biochemistry Department, Faculty of Science and Letters. The cells were allowed to grow in Dulbecco's modified Eagle's medium (DMEM D5796, Sigma) which included $1 \%$ penicillin streptomycin (P4333-20ML, Sigma) and 10\% fetal bovine serum (FBS F7524, Sigma) in 75 cm2 culture flasks. Both cell lines were incubated at $37{ }^{\circ} \mathrm{C}, 5 \% \mathrm{CO} 2$ and $70-80 \%$ humidity cell culture. Cell culture investigations were conducted in a Biosafety Cabinet (ESCO, USA). The Gene Pulsar Xcell TM (Bio-Rad, Hercules, CA, USA) equipment was used in ECT experiments at the Eastern Anatolia High Technology Application and Research Center (DAYTAM). Since the experiments are performed on cell lines, there is no need for an ethics committee.

\section{Drug}

A new Schiff base ligand (C12H11N303) and its $\mathrm{Ru}(\mathrm{II})$ and $\mathrm{Co}(\mathrm{II})$ complexes $[\mathrm{RuCl}(\mathrm{p}$ cymene)L], [CoCl-L(H2O)2]·2H2O were used in this study, which were synthesized from the basic material cytosine (4-aminopyrimidine-2 (1H) -one) and described previously (Figure 1) ${ }^{13}$. To prepare a stock solution, cytosine and compounds were dissolved in the RPMI-1640 medium (Sigma, USA). For chemotherapy and ECT treatment, cells were subjected to different concentrations of cytosine, ligand, Ru (II), and Co (II) complexes. 


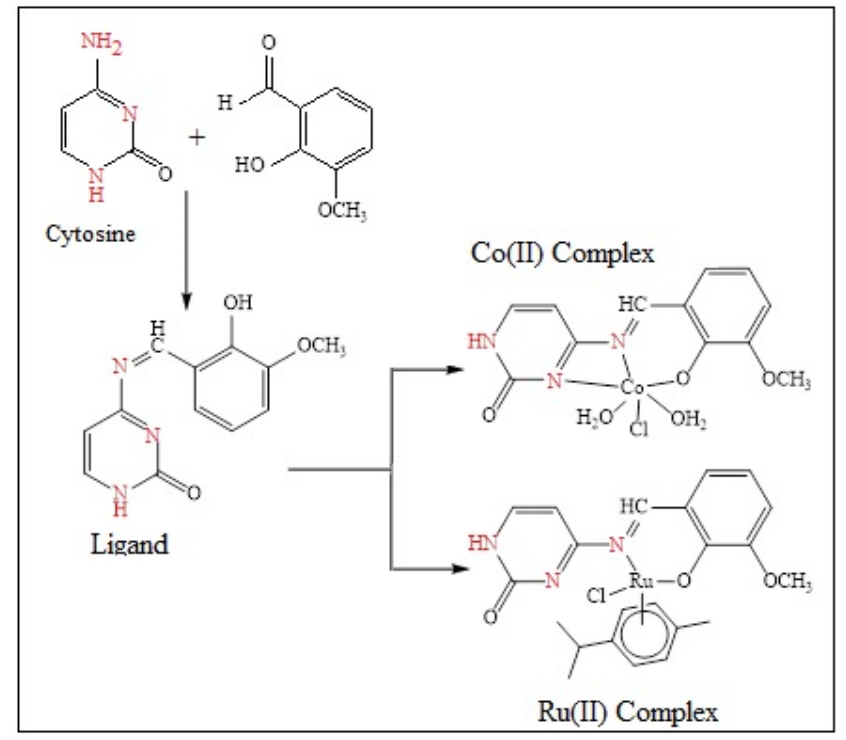

Figure 1. The structures of ligand and its Cobalt(II) and Ruthenium(II) complexes ${ }^{13}$

\section{Chemotherapy}

Cells were planted in 96-well plates at a density of $1 \times 104$ cells per well and incubated for 24 hours in an incubator containing 5\% CO2. Then, media fluids of the wells were removed and compounds (cytosine, ligand, Co (II) or Ru (II)) were added to each well at the concentrations of $100,200,300,400$, and $500 \mu \mathrm{M}$, and the cells were incubated for another 24 hours. The cells in the control wells were only added $100 \mu \mathrm{L}$ of medium ${ }^{14}$. Cytotoxicity activities of compounds on both cell lines (MCF-7 and L-929) were determined using the MTT assay after 24 hours of incubation.

\section{Electrochemotherapy (ECT)}

The anticancer effect of compounds alone or compounds plus EP was investigated in MCF-7 cells (Passage No. 6). Eight square wave pulse sequences at $1 \mathrm{~Hz}$ frequency with 100microsecond pulse duration and $800 \mathrm{~V} / \mathrm{cm}$ electric field were applied to the compound + EP group cells. It has been shown in previous studies that these applied ECT parameters are the most suitable values for electroporation of cells $^{15}$. Gene Pulser Xcell ${ }^{\text {тм }}$ (Bio-Rad, Hercules,
CA, USA) was used for ECT applications. Before electroporation, compounds were added to the cell suspensions ( 1 x 106 cells/ml) at $200 \mu \mathrm{M}$ concentration and $400 \mu \mathrm{l}$ of each cell suspension was put into 4 millimeters (mm) EP cuvettes (Bio-Rad). The control cells were put into $4 \mathrm{~mm} \mathrm{EP}$ cuvettes in the same circumstances as the test cells, but there was no electric field applied. After the EP, cells were incubated for $20 \mathrm{~min}$ at room temperature, then transferred to 24-well plates and allowed to incubate for 24 hours at $37{ }^{\circ} \mathrm{C}$ humid environment. Viability of cells was evaluated by MTT assay.

\section{MTT cell viability assay}

The 3 (4,5-dimethylthiazol-2-yl)-2,5diphenyltetrazolium bromide (MTT) assay (Invitrogen, GIBCO, USA) was used to determine the viability of the cells following chemotherapy and ECT treatment ${ }^{14} .50 \mathrm{mg}$ MTT was dissolved in $10 \mathrm{~mL}$ Dulbecco Phosphate Buffered Serum and covered with aluminum foil to prevent light, and stored at $+4^{\circ} \mathrm{C}$ until use. The culture plates, which had been incubated for 24 hours after adding the compounds, were taken and the medium liquid was discarded from the wells. Then each well was added $90 \mu \mathrm{L}$ media and 10 $\mu \mathrm{L}$ MTT solution and the plates were incubated for 4 hours at $37^{\circ} \mathrm{C}$ in a $5 \% \mathrm{CO} 2$ medium. After 4 hours of incubation, the MTT solution was discarded and $100 \mu \mathrm{l}$ dimethylsulphoxide (DMSO) was put in each well and mixed to dissolve the crystals of formazan that have developed in the wells. The color density formed in the wells was determined at $540 \mathrm{~nm}$ with a spectrophotometer (Thermo Fisher Scientific, FI-01620 Vantaa, Finland). For each compound, the concentration causing 50\% inhibition (IC50) was calculated from doseresponse curves by the regression equation. The IC50 value of each compound was reached after 4 independent experiments. 


\section{Statistical Analysis}

Statistical analyzes were performed using the Graph Pad Prism program (Graph Pad Software Inc., San Diego, USA). All of the experiments were repeated three times, and the results are shown as mean \pm standard deviation. The results were analyzed by one-way ANOVA followed by Tukey multiple comparison tests, or by a two-independent sample $t$ test (Nonparametric) where it was appropriate. Probability values of $\mathrm{p}<0.05$ were defined as statistically significant.

\section{RESULTS}

\section{Chemotherapy with compounds}

Human breast cancer cell line MCF-7 and healthy fibroblast cell line L-929 were used to examine the cytotoxicity of the synthesized complexes on normal healthy cells and cancer cells. Cells were treated with six various doses $(0 \mu \mathrm{M}, 100 \mu \mathrm{M}, 200 \mu \mathrm{M}, 300 \mu \mathrm{M}, 400 \mu \mathrm{M}$, and $500 \mu \mathrm{M}$ ) of cytosine, ligand (L), and ligand's complexes Ru (II) and Co (II) for 24 hours. The MTT assay was employed to determine the inhibition of cell proliferation and the IC50 values of the compounds were computed for all cell lines (Table I).

Table I: IC50 values of the cytosine, ligand and ligand's $\mathrm{Ru}(\mathrm{II}), \mathrm{Co}(\mathrm{II})$ complexes in the L-929 and MCF-7 cells for 24 hours' incubation.

\begin{tabular}{|l|c|c|}
\hline Compounds & $\begin{array}{c}\text { L-929 } \\
\text { IC } 5 \mathbf{5 0}(\boldsymbol{\mu M})\end{array}$ & $\begin{array}{c}\text { MCF-7 } \\
\text { IC50 }(\boldsymbol{\mu M})\end{array}$ \\
\hline Cytosine & 1340.2 & 956.45 \\
Co(II) complex & 1008.7 & 758.22 \\
$\operatorname{Ru}(\mathrm{II})$ complex & 1213.3 & 521.21 \\
& & 470.89 \\
\hline
\end{tabular}

The cytotoxic effects of the compounds were evaluated according to their IC50 values. High IC50 values indicate low cytotoxicity, while low IC50 values indicate high cytotoxicity. Co (II) and $\mathrm{Ru}$ (II) compounds showed best cytotoxicity against MCF-7 cancer cells with IC50 $=521.2 \mu \mathrm{M}$ and IC50 $=470.9 \mu \mathrm{M}$, while they displayed low cytotoxicity against L-929 healthy cells with IC50 $=1008,7 \mu \mathrm{M}$ and IC50 = $1213.3 \mu \mathrm{M}$, respectively. The main material cytosine showed low cytotoxicity with IC50 = $956.45 \mu \mathrm{M}$ in the MCF-7 cancer cells and IC50 = 1340.2 $\mu \mathrm{M}$ in the L-929 cell line. Ligand also demonstrated a cytotoxic effect in both cell lines, but was not as effective as its Co (II) and $\mathrm{Ru}$ (II) complexes.

Agents used for chemotherapy must have the ability to kill cancer cells without damaging healthy cells. Therefore, researchers are trying to discover and develop chemotherapeutic agents that will show effective cytotoxicity against cancer cells and compatible with normal cells. In the present study, L-929 healthy fibroblast cells were treated with various doses of cytosine, ligand, $\mathrm{Ru}(\mathrm{II})$, and $\mathrm{Co}(\mathrm{II})$ complexes for 24 hours. The compounds started to cause inhibition in healthy L-929 cells after $200 \mu \mathrm{M}$ concentration. For this reason, a $200 \mu \mathrm{M}$ concentration of cytosine, ligand, Co(II), and $\mathrm{Ru}(\mathrm{II})$ compounds were used for ECT studies.

\section{Efficiency of electrochemotherapy}

Cell viability percentages of the agent (cytosine, ligand, Co or $\mathrm{Ru}$ ) and agent+electroporation groups were measured by MTT test after 24 hours of incubation, and the results are shown in Figure 2 as mean \pm standard deviation. 


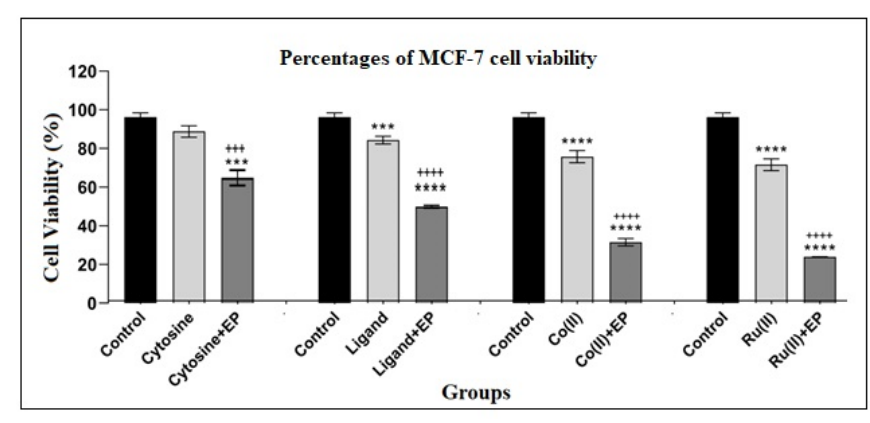

Figure 2. Percentages of cell viability of MCF-7 cancer cells at 24 hours after treatment. *: Significant compared to the control group ( $\mathrm{p}<0.05) ;+$ : Significant compared to compound-alone treatment group $(\mathrm{p}<0.05)$. Data from five independent experiments were presented as mean \pm SD.

A statistically significant decrease was observed in the percentages of cell viability of ligand, $\mathrm{Co}(\mathrm{II})$, and $\mathrm{Ru}(\mathrm{II})$ therapy groups compared to the control group $(\mathrm{p}<0.05)$. As seen in Figure 2, combined therapy of compound and EP led to a significant reduction in viability of MCF-7 cancer cells $(p<0.05)$. The ligand and its complexes showed better anticancer activity than cytosine in ECT, as in chemotherapy. Ligand+EP showed mild cytotoxicity, while Co(II)+EP and Ru(II)+EP demonstrated promising anticancer activity by reducing the viability of MCF-7 cells to $36,56 \%$ and $29.73 \%$, respectively.

\section{DISCUSSION}

Schiff bases and metal compounds have been frequently used in medicinal chemistry and drug design and development ${ }^{16}$. Cobalt (Co), one of the important trace elements found in all animals, has a significant part in many activities that have biological importance, and is mostly found in the form of cobalamin, also known as vitamin B1217. There is a need for different forms of vitamin B12 in order for red cells to form properly as well as for having a DNA regulation and synthesis and maintaining the normal functions of brain and nerves. Co comes to forefront in this regard since it has a lower toxicity to human beings than the non-essential metals such as platinum. Ruthenium $(\mathrm{Ru})$ compounds also have a potential for being a drug candidate. In the researches examining its anti-tumor potential, it was reported that the complex highly inhibited the functions of topoisomerase II, and this is significant for mitotic chromosome scaffold to structurally organize during the cell replication ${ }^{18}$. Previous researches also reported that some of the $\mathrm{Ru}$ compounds were capable of inhibiting the DNA replication, producing a mutagenic effect, inducing SOS repair, binding to DNA, and reducing the synthesis of $\mathrm{RNA}^{8,19}$. These advantages motivated many researchers to examine the compounds that contain Co and $\mathrm{Ru}$ as alternatives to the platinum-based anticancer drugs. Considering the fascinating biological activities of $\mathrm{Ru}(\mathrm{II})$ and $\mathrm{Co}(\mathrm{II})$ complexes and the ligand, this study was designed to investigate their anti-cancer activities against breast cancer. It was found that $\mathrm{Co}(\mathrm{II})$ and $\mathrm{Ru}(\mathrm{II})$ compounds showed best cytotoxicity against MCF-7 cancer cells with IC50 $=521.2 \mu \mathrm{M}$ and IC50 $=470.9 \mu \mathrm{M}$, while they displayed low cytotoxicity against L-929 healthy cells with IC50 $=1008.7 \mu \mathrm{M}$ and IC50 $=$ $1213.3 \mu \mathrm{M}$, respectively. These results are consistent with the findings of previous studies of $\mathrm{Co}(\mathrm{II})$ and $\mathrm{Ru}(\mathrm{II})$ on different cell lines ${ }^{20,21}$. Lida et al. ${ }^{20}$ reported that $\mathrm{Ru}$-arene compounds are potential anticancer agents that prevent metastasis and progression by inhibiting several pathways for various cancer types. Dhahagani et al. ${ }^{21}$ examined the Schiff base complex of $\mathrm{Co}(\mathrm{II})$ that contains 4- (4aminophenyl) morpholine derivatives and found that it displayed very weak activities against the hepatocellular carcinoma cells (HepG2). Furthermore, it was reported that the Co(II) complexes that contain 2,6-bis (2,6diethylphenyliminomethyl) pyridine displayed good cytotoxicity in the HeLa and HCT-15 cells $^{22}$. The biological characteristics of ligands significantly affect the activities of complex compounds and therefore, they should be taken into considerations in developing a cancer 
drug23. The most important goal for anti-cancer agents in the cell is DNA. DNA contact with $\mathrm{Ru}(\mathrm{II})$ and $\mathrm{Co}(\mathrm{II})$ metal complexes may cause the deterioration of DNA and the death of cells. It is a common acceptance that $\mathrm{Ru}$ (II) complexes' cytotoxicity is associated with their capacity to bind DNA ${ }^{10}$.

Electrochemotherapy combined with a variety of medications has been shown to be successful in a number of in vitro and in vivo studies. Fiorentzis et al. ${ }^{24}$ reported that the effects of cisplatin and bleomycin were risen 3-15 times and 8-70 times, respectively, in human uveal melanoma cells by electrochemotherapy. ECT is also used in locally treating the cutaneous/subcutaneous metastatic breast cancers $^{25}$. Not only the small tumors but also the large ones caused by breast cancer have been treated by ECT effectively up to now. Wichtowski et al. ${ }^{26}$ asserted that ECT has high efficiency in treating cutaneous breast cancer metastases. Eşmeyekaya et al. ${ }^{27}$ reported that the EP applications caused an increase in the absorption of tamoxifen into MCF-7 cells and decreased the minimum tamoxifen dose which is required for breast cancer treatment. Electroporation applications increase the absorption of compounds into the cell, and by doing so, considerably enhance their anticancer effect ${ }^{28}$. In this study, EP increased the cytotoxicity of the compounds significantly $(\mathrm{p}<0.05)$. A statistically significant decrease was detected in the percentages of cell viability of ligand+EP, Co(II)+EP, and $\mathrm{Ru}(\mathrm{II})+\mathrm{EP}$ treatment groups compared to the compounds-alone and control groups ( $p<0.05$ ). The eight-squarewave pulse sequence with an electric field of $800 \mathrm{~V} / \mathrm{cm} \quad(1 \mathrm{~Hz}$ frequency and 100 microseconds pulse duration) may have increased the cytotoxicity of the compounds by increasing the permeability and electrical conductivity of the MCF-7 cells membrane. Because, if the applied electric field surpasses a critical level, some temporary pores are formed in the cell membrane and it causes a significant enhancement in the permeability and electrical conductivity of the membrane ${ }^{12}$. In this way, the entry of chemotherapy agents into cells can be facilitated and their cytotoxicity can be increased. In addition, when the tumor tissues are subjected to electric impulses, the blood circulation of the tumor decreases by up to $80 \%$ and becomes normal in 24 hours, allowing the drug to remain in the tumor tissues for a prolonged period of time and show its effect ${ }^{29}$. In the previous researches, it has been revealed that the chemotherapeutic drugs mainly focus on dividing the cancer cells while not dividing the normal cells in the vicinity ${ }^{29}$. In their study examining the differences between malignant melanoma and normal primary cells in terms of their capacity of repairing membrane, Frandsen et al. ${ }^{30}$ reported that the normal primary cells exhibited a better membrane repair capacity and asserted that this finding might explain why other therapy methods where the plasma membrane is made permeable affect the malignant cells more than the normal ones in cancer treatments. ECT can be preferred as a primary local treatment in patients with breast cancer who cannot be treated with other treatment methods.

\section{CONCLUSION}

The compounds of Cobalt(II) and Ruthenium(II) show promise in developing novel anti-cancer drugs since they exhibited remarkably cytotoxic effect and showed a better affinity with the MCF-7 cancer cells than the L-929 healthy cells. They are aqueous-soluble, which makes them show promise in terms of anti-cancer activity. Moreover, $\mathrm{Ru}(\mathrm{II})+\mathrm{EP}$ and $\mathrm{Co}(\mathrm{II})+\mathrm{EP}$ demonstrated promising anticancer activity by reducing the viability of MCF-7 cells to $36.56 \%$ and $29.73 \%$, respectively. In the therapy of MCF-7 cancer cells, using compounds in combination with EP was far more effective than using compounds alone. Electrochemotherapy can reduce the side 
effects of drugs in breast cancer patients by providing treatment with a lower dose of medicines and in a short period time. More research with different drugs and cell lines is needed to reach more conclusive results.

Acknowledgments: I thank to Dr. Kenan Buldurun, Dr. Yusuf Alan, Dr. Nevin Turan of Muş Alparslan University for their valuable contributions.

Ethics Committee Approval: Since the experiments are performed on cell lines, there is no need for an ethics committee.

Declaration of Conflicting Interests: The authors declare that they have no conflict of interest.

Financial Disclosure: No financial support was received.

\section{REFERENCES}

1. Bray F, Ferlay J, Soerjomataram I, et al. Global cancer statistics 2018: GLOBOCAN estimates of incidence and mortality worldwide for 36 cancers in 185 countries. CA Cancer J Clin. 2018; 68: 394-424.

2. Levitsky DO, Dembitsky VM. Anti-breast cancer agents derived from plants. Nat Products Bioprospect. 2014; 5: 1-16.

3. Michel O, Kulbacka J, Saczko J, et al. Electroporation with cisplatin against metastatic pancreatic cancer: In Vitro Study on human primary cell culture. Biomed Res Int. 2018; 2018: 1-12.

4. Çiftci F. The role of breast-conserving surgery in the treatment of early-stage breast cancer. Dicle Med J. 2020; 852-8.

5. Housman G, Byler S, Heerboth S, et al. Drug resistance in cancer: an overview. Cancers (Basel). 2014; 6: 1769-92.

6. Ramesh G, Daravath S, Ganji N, et al. Facile synthesis, structural characterization, DNA binding, incision evaluation, antioxidant and antimicrobial activity studies of Cobalt (II), Nickle (II) and Copper (II) complexes of 3-amino-5-(4-fluorophenyl) isoxazole derivatives. J Mol Struct. 2020; 1202: 127338.
7. Thamilarasan V, Sengottuvelan N, Sudha A, Srinivasan P, Chakkaravarthi G. Cobalt (III) complexes as potential anticancer agents: Physicochemical, structural, cytotoxic activity and DNA/protein interactions. J Photochem Photobiol B. 2016; 162: 558-69.

8. Motswainyana WM, Ajibade PA. Anticancer activities of mononuclear ruthenium(II) coordination complexes. Adv Chem. 2015; 2015: 121.

9. Zhu J, Wang F, Liu X, Tan L. Stabilization of an intermolecular RNA triplex by two novel binders Lys- and Arg-rich $\mathrm{Ru}(\mathrm{II})$ polypyridyl metallopeptides. J Inorg Biochem. 2020; 210: 111171.

10. Thota S, Rodrigues DA, Crans DC, Barreiro EJ. Ru (II) Compounds: Next-Generation Anticancer Metallotherapeutics? J Med Chem. 2018; 61: 58055821.

11. Clover AJP, Salwa SP, Bourke MG, et al. Electrochemotherapy for the treatment of primary basal cell carcinoma; A randomised control trial comparing electrochemotherapy and surgery with five year follow up. Eur J Surg Oncol. 2020; 46: 84754.

12. Probst U, Fuhrmann I, Beyer L, Wiggermann P. Electrochemotherapy as a new modality in interventional oncology: A review. Technol Cancer Res Treat. 2018; 17: 153303381878532.

13. Alkış ME, Keleştemür Ü, Alan Y, Turan N, Buldurun K. Cobalt and ruthenium complexes with pyrimidine based schiff base: Synthesis, characterization, anticancer activities and electrochemotherapy efficiency. J Mol Struct. 2021; 1226: 129402.

14. Alkış ME, Buldurun K, Turan N, et al. Synthesis, characterization, antiproliferative of pyrimidine based ligand and its Ni(II) and Pd(II) complexes and effectiveness of electroporation. J Biomol Struct Dyn. 2020; 1-11.

15. Campana LG, Miklavčič D, Bertino G, et al. Electrochemotherapy of superficial tumors Current status: Basic principles, operating procedures, shared indications, and emerging applications. Semin Oncol. 2019; 46: 173-91. 
16. Kenny RG, Marmion CJ. Toward multi-targeted platinum and ruthenium drugs-A new paradigm in cancer drug treatment regimens? Chem Rev. 2019; 119: 1058-137.

17. Munteanu CR, Suntharalingam K. Advances in cobalt complexes as anticancer agents. Dalton Transactions. 2015; 44: 13796-808.

18. Zheng W, Zhao Y, Luo Q, et al. Rational design of multi-targeting ruthenium- and platinum-based anticancer complexes. Science China Chemistry. 2016; 59: 1240-9.

19. Da Silva MM, Camargo MS, Correa RS, et al. Nonmutagenic $\mathrm{Ru}$ (II) complexes: cytotoxicity, topoisomerase IB inhibition, DNA and HSA binding. Dalton Transactions. 2019; 48: 14885-97.

20. Iida J, Bell-Loncella ET, Purazo ML, et al. Inhibition of cancer cell growth by ruthenium complexes. J Transl Med. 2016; 14: 48.

21. Dhahagani K, Mathan Kumar S, Chakkaravarthi G, et al. Synthesis and spectral characterization of Schiff base complexes of $\mathrm{Cu}$ (II), Co (II), Zn (II) and VO (IV) containing 4-(4-aminophenyl) morpholine derivatives: Antimicrobial evaluation and anticancer studies. Spectrochim Acta A Mol Biomol Spectrosc. 2014; 117: 87-94.

22. Martinez-Bulit P, Garza-Ortíz A, Mijangos E, et al. 2,6-Bis(2,6-diethyl phenylimino methyl) pyridine coordination compounds with cobalt (II), nickel (II), copper (II), and zinc (II): synthesis, spectroscopic characterization, X-ray study and in vitro cytotoxicity. J Inorg Biochem. 2015; 142: 1-7.

23. Ritacco I, Russo N, Sicilia E. DFT investigation of the mechanism of action of organoiridium(III) complexes as anticancer agents. Inorg Chem. 2015; 54: 10801-10.

24. Fiorentzis $M$, Kalirai $H$, Katopodis $P$, et al. Electrochemotherapy with bleomycin and cisplatin enhances cytotoxicity in primary and metastatic uveal melanoma cell lines in vitro. Neoplasma. 2018; 65: 210-5.

25. Schmidt G, Juhasz-Böss I, Solomayer E-F, Herr D. Electrochemotherapy in breast cancer: A review of references. Geburtshilfe Frauenheilkd. 2014; 74: 557-62.

26. Wichtowski M, Murawa D, Czarnecki R, et al. Electrochemotherapy in the Treatment of Breast Cancer Metastasis to the Skin and Subcutaneous Tissue - Multicenter Experience. Oncol Res Treat. 2018; 42: 47-51.

27. Esmekaya MA, Kayhan H, Yagci M, Coskun A, Canseven AG. Effects of electroporation on tamoxifen delivery in estrogen receptor positive (ER+) human breast carcinoma cells. Cell Biochem Biophys. 2017; 75: 103-9.

28. Mittal L, Aryal UK, Camarillo IG, Raman V, Sundararajan R. Effective electrochemotherapy with curcumin in MDA-MB-231-human, triple negative breast cancer cells: A global proteomics study. Bioelectrochemistry. 2020; 131: 107350.

29. Esmaeili N, Friebe M. Electrochemotherapy: A review of current status, alternative IGP approaches, and future perspectives. J Healthc Eng. 2019; 2019: $1-11$

30. Frandsen SK, McNeil AK, Novak I, McNeil PL, Gehl J. Difference in membrane repair capacity between cancer cell lines and a normal cell line. J Membr Biol. 2016; 249: 569-76. 